\title{
The Use Of Social Media In The Ability Of Self Regulated Learning On Teacher Education Students Of Early Childhood Education
}

\author{
Isabella Hasiana ${ }^{a}$, Elisabeth Christiana ${ }^{b}$ \\ ${ }^{a}$ PGRI Adi Buana Surabaya University, Indonesia \\ ${ }^{\mathrm{b}}$ Surabaya State University, Surabaya, Indonesia \\ e-mail: isabella@unipasby.ac.id
}

\begin{abstract}
This study aims to determine the description of self-regulated learning in Teachers Education Teacher Education Early Childhood. Self Regulated Learning is an activity where individuals have the ability to learn actively and individuals have the ability to plan, set goals, organize, self-monitor and self-evaluate. This process allows the individual to become self-aware, knowing and determining the learning approach. The type of research used is descriptive qualitative. Subjects involving a number of six students, with the technique of taking subjects using purposive sampling techniques. Data collection techniques were conducted using semi-structured interviews. The results showed that the self regulated learning picture on each subject is quite diverse. Three subjects have good self regulated learning abilities. This is because they already have the ability to control the time, have a plan in managing the tasks of college. While the other three subjects, yet can maximize self regulated learning in him. This is because: 1). Assuming that is still the initial semester, 2). Inability to control time, 3). In the course of work the lectures tend to rely on friends, 4). Spend more time using social media.
\end{abstract}

Keywords: $\quad$ self regulated learning, social media, student

\section{INTRODUCTION}

Education for humans is very important. This is due to the existence of education, individuals will be able to develop all the potential that they have in order to achieve the educational goals of achieving maturity.

Education is obtained through the learning process. The learning process is a series of mental and physical activities to obtain a change in behavior as a result of individual experience in interaction with the surrounding environment (Rachmandasari, 2012). Individual success in education can be seen from the learning achievements that have been obtained. According to Slameto (Rachmandasari, 2012), there are two factors that influence individuals in the learning process. First, internal factors which consist of physical and psychological factors. Second, external factors, namely family and school factors. Apart from these two factors, there are other factors, namely the ability of self regulated learning. This ability is needed for individuals to have success in achieving optimal learning achievement

In the study of undergraduate level in college, of course it is expected that individuals have the ability to self regulated learning. So that individuals can complete the study within $4-5$ years. This course must be done with all my heart and supported by a lot of preparation. But in reality, not a few students were "lazy" in completing college assignments and attendance at lectures. This happens especially for first-year students who still need adjustments to the conditions of the lecture.

The conditions of the learning process at the college level with the secondary school level are certainly different. At the lecture level, students are expected to have independence in learning. This is 
what students have not had in the first year. The impact is that there are courses that repeat so that it will have an impact on the final work process so that the completion of the study is also not timely.

Students who are generally between the ages of 18-22 are students who are required to be more independent and responsible in their learning. But in reality, students sometimes are not responsible for learning. For example, when students who use smartphones to interact on social media for long periods of time can interfere with learning time. This is as expressed by one of the speakers to the author who said that when using a smartphone for hours to interact on social media, the resource person lost his enthusiasm for learning (interview, April 18, 2018).

Initial observations made by researchers of first year students, it was found that when the work was done the task tended to be done in a short time.

The task of college which in the process requires internet, often makes students less able to focus on their work. The desire to use social media is greater than when searching for information from the internet related to their duties (interview, April 20, 2018)

Today, technological progress is growing rapidly. One of the fastest growing technologies is the development of internet networks. Individual interest in the internet depends on the interests, interests, and personality of each individual such as interest in the use of social media.

Indonesia's population currently reaches 262 million people. More than 50 percent or around 143 million people have been connected to the internet network. While internet users as much as 49.52 percent are aged 19 to 34 years.

(https://tekno.kompas.com/read/2018/02/22/16 453177/berapa-jilangan-pengguna-internetindonesia).

Based on the results of research conducted by Duncan, et al (http://repository.wima.ac.id/9494/2/BAB\%201.pdf) found 75 percent of students use smartphones and 25 percent of students use laptops during the learning process in the classroom take place.

Excessive use of smartphones can disrupt the learning time of a student including students. As expressed by students of early childhood education program, who said when he used a smartphone to access social networks in his smartphone, he felt his concentration was disrupted while learning and even forgot his obligations as a student to study or do college work because he could not focus.
Research conducted by Parmuarip, et al (http://repository.uksw.edu/bitstream/123456789/90 10/2/T1_802010114_Full\%20text.pdf) concerning Reasons for Using Smartphones in Bandung State Polytechnic Students which concluded that the reason for smartphone users among Bandung Polytechnic students are one of them using smartphone multimedia as a means of finding information and learning. The negative impact of smartphone use is that it can cause user addiction or dependence on the results of the development of communication technology can cause Digital Dementia (digital senility that afflicts young people who are heavily addicted to gagdet) or a decrease in cognitive abilities that is difficult to remember (http: // repository. uksw.edu/bitstream/1 23456789/9010/2/T1_802010114_Full\%20text.pdf).

Social media can now be easier to access because it can be opened with a portable device. Nowadays social media is a very important thing in people's lives, starting from the world of business, education, to industry. Social media has a very vital role in community life. Information dissemination both in writing and in pictures is easier to obtain. Social media pages like Twitter, Facebook, Instagram, and other social media have become a routine in individuals.

Not infrequently also social media is one of the alternative options to discuss group work and communicate between the academic community. Social media is also used as a medium to find and exchange information relevant to academic tasks.

Students who experience addiction to smartphones will certainly interfere with Self Regulation Learning because they experience cognitive decline. Where self regulation learning is closely related to cognition.

Gadget usage behavior that is not related to academic processes in students is known as cyberfloating behavior.

Cyberfloating is a state when an individual intentionally uses internet technology facilities provided or personal devices (smartphone, ipad) for personal purposes that are not related to work during working hours. This behavior can be in the form of sending e-mails in the form of jokes to friends, doing online shopping, playing games, downloading music, sending short messages, and accessing the internet that has nothing to do with work (Rogelberg in http://repository.wima.ac.id /9494/2/BAB $\% 201$.pdf). This study focuses on students who use internet facilities and has nothing to do with 
academic activities during class and during learning, examples of social media.

One important factor determining the occurrence of cyberfloating is the behavior of self regulation. Individuals who are unable to regulate themselves will produce counterproductive behavior. In addition, if students have high self-regulation, they will give attention and focus during the class while students who have low self-regulation will tend to be active with their cellphones.

Self regulated learning as a process when students are personally active and encourage cognition, behavior and feelings systematically and oriented towards the achievement of learning objectives. Self regulated learning is considered as an important factor for academic motivation and student achievement. Individuals who have the ability to self regulated learning will be responsible for regulating their behavior and learning environment, controlling the surrounding environment in terms of limiting the factors that will interfere with their learning activities (http://repository.wima.ac.id/9494/2/BAB \% 201.pdf).

Santrock (2008) mentions the existence of selfregulation (self regulated learning) in learning will make individuals able to regulate academic and socio-emotional goals, evaluate and make adaptations needed to achieve the specified achievements. Self regulated learning is a person's ability to regulate themselves in learning accompanied by discipline in maintaining thoughts, feelings and behavior to achieve academic goals.

In addition, self-management or self regulation is not a mental ability such as intelligence or academic skills such as reading skills. But it is a process of directing or instructing individuals to change their mental abilities into skills in a form of activity (Ghufron and Risnawita, 2010).

Zimmerman (Woolfolk, 2008) defines selfregulated learning as a condition in which individuals who learn as controlling their own learning activities, monitor motivation and academic goals, manage human and material resources, and become behaviors in the decision-making process and implementers in the learning process.

Therefore, the ability of self regulated learning must be owned by individuals. So that there is a priority scale that must be selected and determined. Between the use of social media and the task of learning becomes unbalanced. This was confirmed in interviews conducted on research subjects, who said that when asked to look for lecture materials on the internet, they were tempted to open social media pages. Interest in doing activities on social media often takes up their time in learning. (interview April 18 2018).

xisting research shows that internet addiction has a negative correlation with self regulated learning. That is, students with internet addiction spend some time in front of the internet, making students run out of time to do their obligations as students (Nathanael and Sandjaja, 2017).

Self regulated learning covers three aspects, namely 1). Metacognitive, is the ability of the process to understand and sort out learning approaches and things that need to be done in a given situation; 2). Motivation, is an individual's interest in the task given and strives diligently in learning to choose, compile, and create a preferred environment for learning; 3). Behavior is an effort in individuals to organize themselves, select, utilize, and create an environment that optimizes the achievement of the activities carried out.

In developing the ability of self regulated learning, there are factors that influence, namely external factors and internal factors.

External factors provide a standard for evaluating behavior. Environmental factors interact with personal influences, forming a person's selfevaluation standard. Through parents and teachers children learn good and bad, desired behavior and unwanted. Through the experience of interacting with a wider environment individuals can develop standards that will be used to assess selfperformance.

External factors influence self regulation in the form of reinforcement. Intrinsic factors do not always give satisfaction, people need incentives that come from the external environment. Standards of behavior and reinforcement usually work together, when people can achieve certain standards of behavior, it needs strengthening so that such behavior becomes an option to do again.

External factors interact with internal factors in self-regulation. Bandura proposed three forms of internal influence, namely: 1). Self observation (self observation) is carried out based on factors of appearance quality, quantity of appearance, original self behavior, and so on. Individuals must be able to monitor their performance, even though it is not perfect because others tend to choose some aspects of their behavior and ignore their other behavior. 2) The assessment process (judgment process), which 
is seeing the suitability of behavior with personal standards, comparing behavior with standard norms or with the behavior of others, assessing the importance of an activity, and giving performance attributions, 3) Affective self-reactions (self response ), based on observation and judgment, people evaluate themselves positively or negatively, and then give a gift or punishment for themselves. Affective reactions can occur, because cognitive functions make a balance that affects positive or negative evaluations to be less meaningful individually.

According to Djamarah, (2002) indicators of self regulated learning are expressed as follows: 1). Awareness of learning goals. Goals are needed in learning. Learning without purpose means nothing is sought. While learning is looking for something from reading material that is read. Then setting learning goals before learning is important. That way, learning becomes focused and concentration can be maintained in a relatively long time when learning, 2). Awareness of learning responsibilities. Learning is an activity carried out to obtain a number of knowledge. In learning, students cannot escape from several things that can lead them to succeed in learning. Many students learn hard, but don't get any results and only failure is encountered. This is due to irregular learning time, lack of discipline in learning, lack of enthusiasm, not knowing how to concentrate, ignoring the problem of time management, insufficient rest, and lack of sleep. For this reason students must have an awareness of learning responsibilities; 3 ). Continuity of Learning. Continuous learning can be interpreted as continuous learning. Repeating lesson material, memorizing lesson material, always doing assignments given by the teacher, and making summaries and summaries are things that are continuous after the students finish studying in class. So that it is expected that students will develop independence when these things become a habit. Continuity in learning can be interpreted by studying regularly which is an absolute guideline that cannot be ignored by someone who is studying; 4). Learning Activity. Students who are accustomed to being active in learning will grow in their learning independence. This is realized by reading books, adding insights from libraries and other sources and can connect the lessons that are being received with material that has been mastered, active and creative in group work, and ask if there are things that are not clear; 5). Learning Efficiency. Efficiency in learning can be interpreted by learning regularly and effectively. This is an absolute guideline that students cannot ignore. The amount of lecture material that is mastered requires a time division that is in accordance with the depth and breadth of the subject matter. Mastery of all learning materials is demanded early, do not have to wait until the exam.

Self regulated learning explains how important autonomy and personal responsibility are in learning activities. In the learning process, students who have self regulated learning build learning goals, try to monitor, regulate, and control their cognition, motivation, and behavior to control the goals that have been made (Yulanda, 2017).

\section{METHOD}

The method used in this study uses a qualitative approach. Through this qualitative approach, it is expected to produce an overview of the object under study thoroughly.

Qualitative research method as a research procedure that produces descriptive data in the form of written or verbal words from people and observed behavior.

This research was conducted in the Early Childhood Education Teacher Education Study Program and the subjects of the study were students in the study program who were in the first year of study.

This study uses a sampling technique that is purposive sampling. Purposive sampling is the technique of determining the subject of research based on certain considerations of the researcher (Sugiyono, 2012). In this purposive sampling technique, researchers set a number of criteria for selecting samples or research subjects. The criteria of the sample or subject of this study are: 1). Students are active in teacher education programs for early childhood education; 2). 2017 class students; 3). Have social media and are active in using it.

The research subject was taken through a questionnaire, which aims to screen students who have social media and are active in using it both as information seekers and entertainment.

Data collection techniques are used using semi-structured interviews, where interviews are used to obtain information directly from the source. In its implementation, this interview uses guidelines that will be able to develop in accordance with the answers and conditions of the informant. 
In addition, data collection techniques also use observation. Observation is defined as an activity of observing directly without going through a mediator of an object with the aim of looking closely at the activities carried out by the object (Sugiyono, 2012).

Data analysis is carried out inductively, meaning that the data collection process is carried out through four stages. That is; 1). Data organization. Includes storage and collection of raw data obtained in research; 2). Perform coding of data. It is data processing by entering the data into certain groups before being given meaning. This process aims to organize the data completely to obtain an overview of the topic under study (Creswell, 2010); 3). Categorize and describe data. Creswell (2010) revealed that the stage after coding is the creation of a theme or category. This categorization is obtained from the interview results which will then be presented in descriptive form; 4). Data interpretation. The last stage in this data analysis is an attempt to understand the results of the overall data that has been obtained.

\section{RESULTS AND DISCUSSION}

From the results of data collection that has been carried out, researchers found that the ability of self regulated learning varied. The results of this study, will reveal five things related to self regulated learning owned by the research subject.

1. Awareness of learning goals

The results showed that, the research subjects who lacked the ability to self regulated learning realized, that they took education in the strata one is certainly not easy. Many obstacles are experienced. One of them is awareness of the learning objectives they are currently living. They want to finish their education on time. But they also realize that often use time to do activities that are less useful. This has an impact on the completion of lecture assignments. They often feel that the completion of the task cannot be carried out optimally. They are less aware that the lectures they are undergoing have goals and objectives. Conversely, for research subjects who have good self regulated learning abilities, those from the beginning of entering the undergraduate level, already have an awareness of the importance of learning goals. This makes them become more focused on what they want to achieve. And this has an impact on the lecture assignments they undergo. If you want to get a satisfactory value, then there must be a learning goal that is set. How do subjects divide their time between college assignments, study course material for tomorrow, and other daily activities. As stated by Ormrod (2008), which states that, "when children and adults become selfregulating students, they set more ambitious goals for themselves, learn more effectively, and achieve higher achievement in the classroom."

\section{Awareness of learning responsibilities}

Awareness of learning responsibilities is also owned by research subjects who have good self regulated learning abilities. They have a good view of the ideal learning process. The ideal learning process, beginning with listening to lectures, reading material after lecture and preparing lecture material. The ideal learning setting according to the research subject is by studying regularly every day, at least one hour a day. And this has an impact on learning outcomes that are very satisfying. A person who has self regulated learning is responsible for their learning activities. They take over their independence to regulate themselves (Nuraini and Supriyatna, 2017). Conversely, with research subjects with less self regulated learning ability, feel more relaxed and not focused on learning preparation. It can be said that awareness of responsibility in learning is still lacking. They assume, with the learning style they are currently living, they still get satisfying learning outcomes. For them, passing an examination on a course is enough to make them satisfied. This is in accordance with what is described by Papalia and Olds (2004) who say that the purpose of college students is success in lectures which are determined by academic achievement and social development.

\section{Continuity of learning.}

Continuity in learning is also related to the learning process undertaken. The activity in repeating the material that has been submitted and preparing the material will further make students have self regulated learning. This is a habit for research subjects who have self reulated learning abilities. whereas in subjects who lack self-regulated learning, this does not appear. According to them, learning activities have been completed when the lecture hours are over. In addition, they rely more on lecture notes from lecturers. In addition, they prefer to open social media pages rather than having to look for lecture materials. This has resulted in them running out of time to work on tasks to interact on 
social media. Students who cannot manage themselves due to frequent interaction on social media will experience a deficit in the metacognitive aspects of self regulated learning, namely decision making and loss of effective learning strategies, making it difficult to follow and learn a lesson (Nathanael and Sandjaja, 2017). This makes students not understand the lesson well and results in the motivation of students with decreased self regulated learning in an effort to understand the lesson (Purnomo, 2013).

\section{Active Learning.}

Learning activity comes from the habit of reading books, searching or browsing from the internet about articles related to lecture material. Besides that, having discussions with friends or lecturers will also help in achieving optimal learning outcomes. This is done by research subjects who have the ability to self regulated learning. They are always active during lectures, actively asking about material that is poorly understood. Conversely, research subjects who lack self-regulated learning do not do the above. The discussion they did with friends and lecturers was limited to working on college assignments. In addition they tend to prefer to ask friends compared to lecturers, or they also try to have their own perception of a material that is sometimes misunderstood. Laziness was found in the subject of this study. Laziness in question is a feeling that the subject will be reluctant to do something because in his mind he has a negative assessment or no desire to do that. This is evident in the lectures carried out, that only certain students are always actively asking questions and responding to lecture material.

\section{Learning efficiency.}

Learning efficiency is certainly related to awareness of learning goals and responsibilities in learning. The existence of an appropriate and effective strategy in the assignment and course material will help students achieve optimal learning outcomes. This attitude appears in research subjects who have the ability to self regulated learning. At the beginning of the lecture, they already have a mindset that there needs to be goals in the educational process taken. Priority scale is needed. So it is not easy to be tempted to carry out activities that are not useful in working on lecture assignments. In contrast, with other research subjects, they said that there was no need to focus too much on lectures. They feel that this level of stratum education is quite easy, more relaxed and fun. For lecture assignments, they assume that it is quite easy, and can be learned. Because it's still sitting in the first year of college.

From the results of interviews that have been conducted, it can be said that the success of individuals in regulating themselves is more influenced by internal factors for research subjects who have the ability to self regulated learning have internal factors that influence. The awareness of learning goals and having responsibility in learning, having an efficient and careful strategy in managing the learning schedule, repeating the material, and preparing the material then become the key to success in regulating oneself. Focusing on the tasks that are done and not easily tempted to open social media pages also has an influence.

Research subjects who have good self regulated learning ability in themselves feel that learning is a process that must be passed. Not only learning during lectures, but activeness in asking questions, curiosity about the material and trying to find material through browsing the internet also helps in developing self regulated learning. This statement is also affirmed by friends and lecturers who teach research subjects. They say that research subjects are students who are independently active. Activeness is seen during lectures where research subjects actively ask. This is also evident from the results of their learning. Research subjects who have good self regulated learning ability are able to achieve a high academic achievement index.

This result is in line with research conducted by Spitzer (2000) who found that self-regulation in learning conducted by a person is closely related to academic performance.

In addition, as stated by Zimmerman \& Schunk (2011) where individuals who have self regulated make learning goals, implement effective learning strategies, monitor and assess the progress of their goals, create a productive environment for learning, and maintain a sense of self efficacy. So that with an increasingly developing environment with technology, individuals can stay focused on their learning goals.

Conversely, for research subjects who lack the ability in self regulated learning say that they are easily divided in concentration. Spending too much time with a smartphone, so it often runs out of time in the task. Excessive use of smartphones can obviously disrupt the learning time of a student including students. Students forget the function of a 
smartphone as a means of finding information and learning (Putranama, 2011). This is also comparable to the academic achievement index achieved by under-average research subjects. Information obtained from the lecturer said that the research subjects often received reprimands in the class because they were busy with their smartphones, the tasks performed were seemingly careless and were done overnight. In addition, classmates of research subjects also said that, they were not included as active students in the class, more silent and busy with their smartphones.

\section{CONCLUSION}

Based on the results of research that has been obtained, it can be concluded that the ability of self regulated learning is an individual effort carried out systematically to focus thoughts, feelings, and behaviors on achieving goals.

The ability of self regulated learning is needed by students to be able to regulate and direct themselves, be able to adjust and control themselves in the face of learning tasks. To have this ability, students are expected to also have a priority scale, able to sort and choose activities that are important, especially in the lecture process and work assignments.

Therefore, with the existence of self regulated learning, students are expected to be able to show behaviors or business that can support their success in the learning process. Besides that, staying focused on learning activities, will also make students have optimal learning outcomes.

\section{REFERENCES}

[1] Creswell. 2010. Research Design Pendekatan Kualitatif, Kuantitatif, Dan Mixed. Edisi Ketiga. Yogyakarta. Pustaka Pelajar

[2] Djamarah. 2002. Rahasia Sukses Belajar. Jakarta : Rineka Cipta.

[3] Ghufron dan Risnawita. 2010. Teori-Teori Psikologi. Jogyakarta : Ar-Ruzz Media

[4] Nathanael dan Sandjaja. 2017. Hubungan antara Internet Addiction dan self regulated learning pada siswa SMP di Kecamatan Karawaci.
Prosiding Konferensi Nasional Peneliti Muda Psikologi Indonesia. Vol 2, No. 1, Hal 27-38.

[5] Nuraini dan Supriyatna. 2017. Kemampuan Self Regulated Learning Siswa Di SMK Yudha Karya Kota Magelang. The 6th University Research Colloqium Universitas Muhammadiyah Magelang.

[6] Ormrod. 2008. Psikologi Pendidikan Membantu Siswa Tumbuh Dan Berkembang. Jakarta : Erlangga.

[7] Papalia \& Olds. 2004. Human Development. New York: Mc Graw-Hill Companies, Inc.

[8] Putranama. 2011. Jurnal Airlangga Pentingnya Blackberry Bagi Pengguna. Diperoleh Dari http://Jurnal\%20Airlangga\%20\%20Pentingnya $\%$ 20Blackberry\%20Bagi\%20Pengguna.html

[9] Purnomo. 2013. Hubungan Antara Pemahaman Materi, Motivasi Belajar, Dan Prestasi Belajar Pada Siswa Kelas VII SMP Taman Dewasa Ibu Pawiyatan Yogyakarta Tahun 2012. EMPHATY Jurnal Fakultas Psikologi, 2(1), 116.

[10] Santrock. 2008. Life-Span Development. Surabaya : Gelora Aksara Pratama

[11] Sugiyono. 2012. Metode Penelitian Kuantitatif Kualitatif dan R\&D. Bandung : Alfabeta

[12] Spitzer, T. M. (2000). Predictor Of College Success: A Comparison Of Traditional And Contraditional Age Student. NASFA Journal 38, 82-98. Diperoleh dari: http://publication.nasfa.org/cgi.viewcontent.cgi? article=1130andconte $=$ nasfajournal.

[13] Wollfolk. 2008. Educational Psychology. Active Learning Edition. Boston : Allyn \& Bacon.

[14] Yulanda. 2017. Pentingnya Self Regulated Learning Bagi Peserta Didik Dalam Penggunaan Gadget. Research And Development Journal Of Education Vol. 3 No. 2 April 2017

[15] Zimmerman. 1986. Development Of Structured Interview For Assessing Student Use Of SelfRegulated Learning Strategies. American Educational Research Journal. 23(4), 641-628

[16] Zimmerman. 2002. Becoming A Self-Regulated Learner: An Overview. College Of Education, The Ohio State University, 41 (2).

[17] Zimmerman and Schunk. 2011. Handbook of Self-Regulation of Learning and Performance. New York \& London : Routledge.

[18] http://repository.wima.ac.id/9494/2/BAB\%201. pdf

[19] http://repository.uksw.edu/bitstream/123456789 /9010/2/T1_802010114_Full\%20text.pdf

[20] http://repository.uksw.edu/bitstream/123456789 /9010/2/T1_802010114_Full\%20text.pdf. 